\title{
SOCS, inflammation, and cancer
}

\author{
Kyoko Inagaki-Ohara', Taisuke Kondo ${ }^{2,3}$, Minako Ito ${ }^{2,3}$, and Akihiko Yoshimura2,3,*
}

\begin{abstract}
'Department of Gastroenterology; Research Center for Hepatitis and Immunology; Research Institute; National Center for Global Health and Medicine (NCGM); Ichikawa, Japan; ${ }^{2}$ Department of Microbiology and Immunology; Keio University School of Medicine; Tokyo, Japan; ${ }^{3}$ Japan Science and Technology Agency (JST); CREST; Tokyo, Japan
\end{abstract}

Keywords: SOCS, STAT, cancer, inflammation, therapeutic target

Signal transduction pathways elicited by cytokines and hormones have been shown to regulate distinct stages of development. Suppressor of cytokine signaling (SOCS) proteins are negative feedback regulators of cytokine signaling mediated by the JAK-STAT signaling pathway. In particular, SOCS1 and SOCS3 are potent inhibitors of JAKs and can play pivotal roles in inflammation, as well as in the development and progression of cancers. Abnormal expression of SOCS1 and SOCS3 in cancer cells has been reported in human carcinoma associated with dysregulation of signals from cytokine receptors, Toll-like receptors (TLRs), and hormone receptors, resulting in malignancies. In this review, we focus on the role of SOCS1 and SOCS3 in cancer development. In addition, the potential of SOCS as a therapeutic target and diagnostic aid will be discussed.

\section{Introduction}

Cytokine signaling mediated by the JAK-STAT pathway plays essential roles in differentiation, maturation, proliferation and apoptosis of a various types of cells, which are involved in initiation and development of cancer. It is well known that a large number of cytokines, growth factors, and hormonal factors activate JAK-STAT pathway proteins. The CIS/suppressor of cytokine signaling (SOCS) proteins are inhibitors of activation of the JAK-STAT pathway. ${ }^{1,2}$ To date, there are over the 900 publications regarding the relationship between the SOCS family and cancer (Fig. 1A). In particular, SOCS1 and SOCS3 are potent inhibitors of this pathway and have been extensively investigated using patient samples and gene-targeted mice. These studies have demonstrated critical roles of SOCS1 and SOCS3 in various malignant processes, such as in inflammation and cancer-10 (Fig. 1B and C).

Cancer results from the outgrowth of a clonal population of cells. The carcinogenesis can be characterized in a number of ways. ${ }^{11}$ Cancer development requires the acquisition of 6 essential alterations in cell physiology: (1) self-sufficiency in growth signals, (2) insensitivity to anti-proliferative signals, (3) the ability to evade apoptosis, (4) limitless replicative potential,

${ }^{*}$ Correspondence to: Akihiko Yoshimura; Email: yoshimura@a6.keio.jp Submitted: 01/21/13; Revised: 02/20/13; Accepted: 02/20/13 Citation: Inagaki-Ohara K, Kondo T, Ito M, Yoshimura A. SOCS, inflammation, and cancer. JAK-STAT 2013; 2:e24053; http://dx.doi.org/10.4161/jkst.24053
(5) sustained angiogenesis, and (6) tissue invasion and metastasis. Cancer also displays a stepwise development, which is grouped into 3 phases: initiation, promotion, and progression. ${ }^{12}$ Although STATs are profoundly associated with these alterations and steps, mutation of STATs is rare. Thus, dysregulation of SOCS family proteins could be one of the mechanisms of abnormal STAT activation. In addition, SOCSs are shown to be involved in viral replication, which can be associated with virus-mediated tumorigenesis. This review focuses mainly on the underlying mechanisms of carcinogenesis related to the JAK-STAT-SOCS pathway, and the pathway's potential therapeutic applications.

\section{The Mechanism of SOCS-Mediated Regulation}

Cytokines play essential roles in the development, differentiation, and apoptosis in a variety of cells. Activation of the JAKSTAT pathway is integral to cytokine and hormone function such as interleukin (IL)-6, IL-11, interferon (IFN)- $\alpha$, granulocyte colony-stimulating factor (G-CSF), leukemia inhibitory factor (LIF), leptin, and prolactin. Cytokine binding to its cognate receptor induces receptor dimerization and activation of Janus protein kinases (JAK), which are constitutively associated with the cytoplasmic chain of the receptor. Once activated, JAK crossphosphorylate each other and specific tyrosine residues on the cytoplasmic domain of the receptor. Phosphorylated tyrosine residues act as docking sites for downstream transcription factors, such as members of the signal transduction and activators of transcription (STAT) family. Activated STAT dimers then translocate to the nucleus where they bind target IFN- $\gamma$-activated (GAS)-like elements, leading to the transcriptional activation of multiple genes. ${ }^{13,14}$

The suppressor of cytokine signaling (SOCS) family of proteins are classical negative feedback regulators of the JAK-STAT signaling pathway. ${ }^{14}$ The mammalian SOCS family consists of 8 members, which include CIS (cytokine-induced SH2 containing protein) and SOCS1 to SOCS7. ${ }^{15}$ There are 4 possible steps that SOCS proteins inhibit cytokine signaling: (1) block STATs recruitment to the cytokine receptor by masking STAT binding sites of the receptor, (2) target proteins for proteosomal degradation via ubiquitination (3) bind to JAKs and inhibiting their kinase, or (4) target JAKs for degradation via the proteasome. ${ }^{16}$ The 8 members of the CIS/SOCS family are characterized by their $\mathrm{N}$-terminal region with variable length and limited homology, a central SH2 domain, and a conserved SOCS box at the 


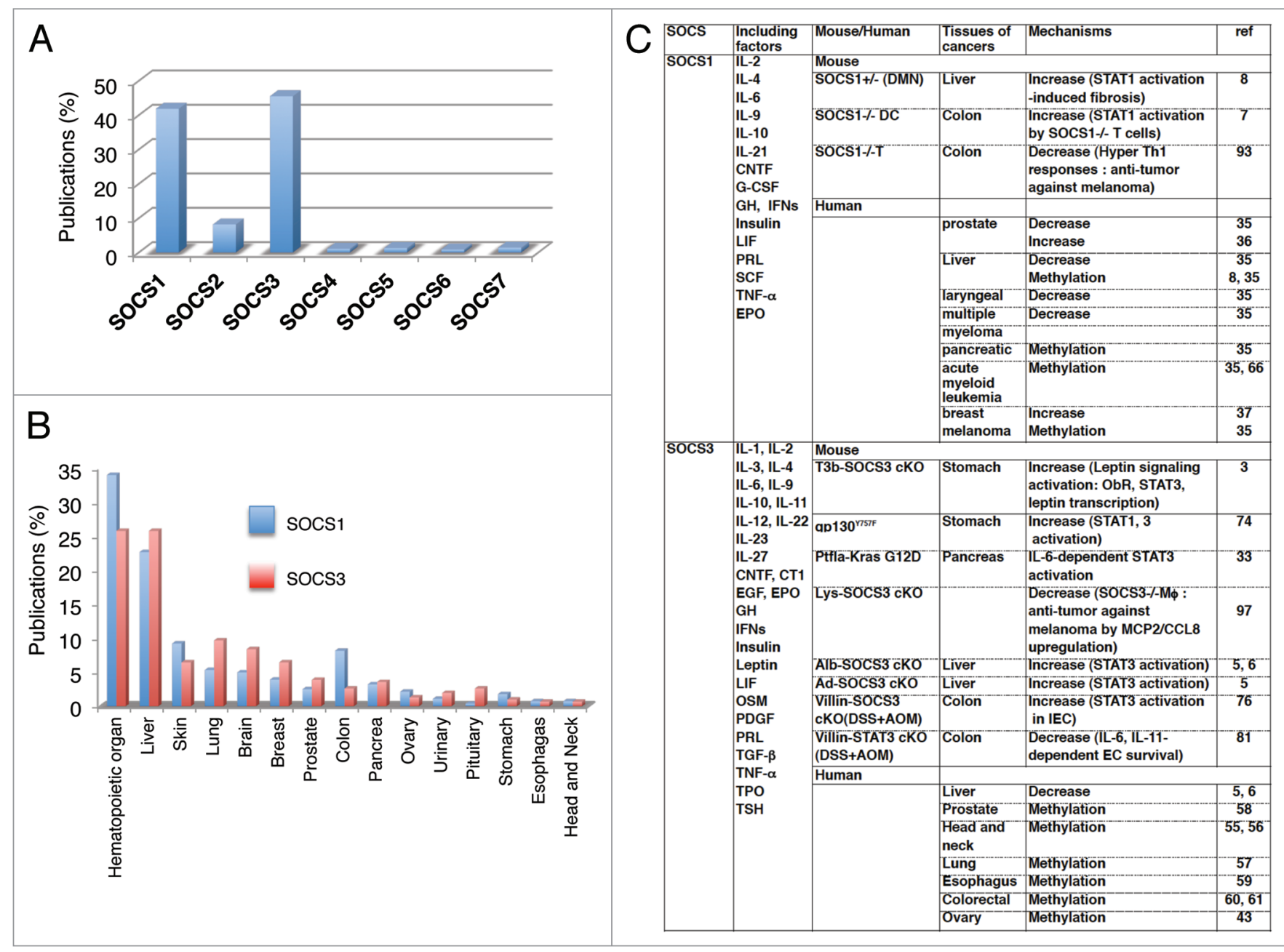

Figure 1. SOCS1 and SOCS3 are critical molecules in the development of cancers. (A) Each bar indicates percentage of publications on each SOCS member by PubMed search. $100 \times$ (each SOCS)/(SOCS1-7). (B) Each bar indicates percentage of publications of SOCS1 and SOCS3 expression for a variety of cancers. (C) Summary of mice and clinical studies that have examined the expression of SOCS1 and SOCS3, and their underlying mechanisms. Abbreviations: AOM, azoxymethane; DSS, dextran sodium sulfate; DMN, dimethylnitrosamine.

C-terminus (Fig. 2A). Functionally, SOCS1 has been shown to directly bind to Jak2 and inhibit its catalytic activity, while SOCS3 binds with high affinity to glycoprotein 130 (gp130)related receptors, including phosphotyrosine (pY)757 of gp130, the pY800 residue of IL-12 receptor $\beta 2$, and the pY985 residue of leptin receptor (ObR). ${ }^{17,18}$ The SOCS box interacts with elongin $\mathrm{B}$ and elongin $\mathrm{C}$, cullin 5, and the RING-finger-domainonly protein RBX2 (which recruits E2 ubiquitin-transferase) (Fig. 2B). ${ }^{16}$ CIS/SOCS family proteins, as well as other SOCSbox-containing molecules, probably function as E2 ubiquitin ligases. Since SOCS molecules bind to several tyrosine-phosphorylated proteins, including Mal (toll-like receptor signaling) and IRS1/2 (insulin signaling), ${ }^{16}$ those targets may also be ubiquitinated by SOCS.

\section{KIR of SOCS1 and SOCS3}

Among the CIS/SOCS members, SOCS1 and SOCS3 have a unique KIR domain, which is essential for suppression of the
JAK tyrosine kinase activity. ${ }^{19}$ KIR has been proposed to function as a pseudosubstrate. It is not clear how SOCS3 inhibits JAK kinase after binding to gp130, despite a low affinity of KIR peptide to JH1. Because the whole SOCS molecule can bind to JH1 with high affinity, we proposed that SOCS3 binds to the receptors first, then moves to the kinase domain by interacting with the phosphorylated activation loop though the $\mathrm{SH} 2$ domain, and then KIR interacts with the catalytic pocket. ${ }^{2}$ A similar mechanism has been proposed for SOCS1; it binds to the IFN $\gamma$ receptor (IFNGR1) first, then binds to JAK2 and inhibits kinase activity. ${ }^{20,21}$ However, recently, Babon et al. showed a new mechanism, in which KIR binds to the surface of JH1, rather than to the catalytic pocket, and induces $\mathrm{s}$ conformational change of $\mathrm{JH}$ to inhibit phosphate transfer from ATP to the substrate peptide. ${ }^{22}$ Importantly, JAK1, JAK2, and Tyk2, but not JAK3, possess an evolutionarily conserved motif unique to JAKs, a GQM motif in the JAK insertion loop. SOCS3 binds and directly inhibits the catalytic domains of JAK1, JAK2, and TYK2, but not JAK3. The gp130 phosphopeptide induces a conformational change of 


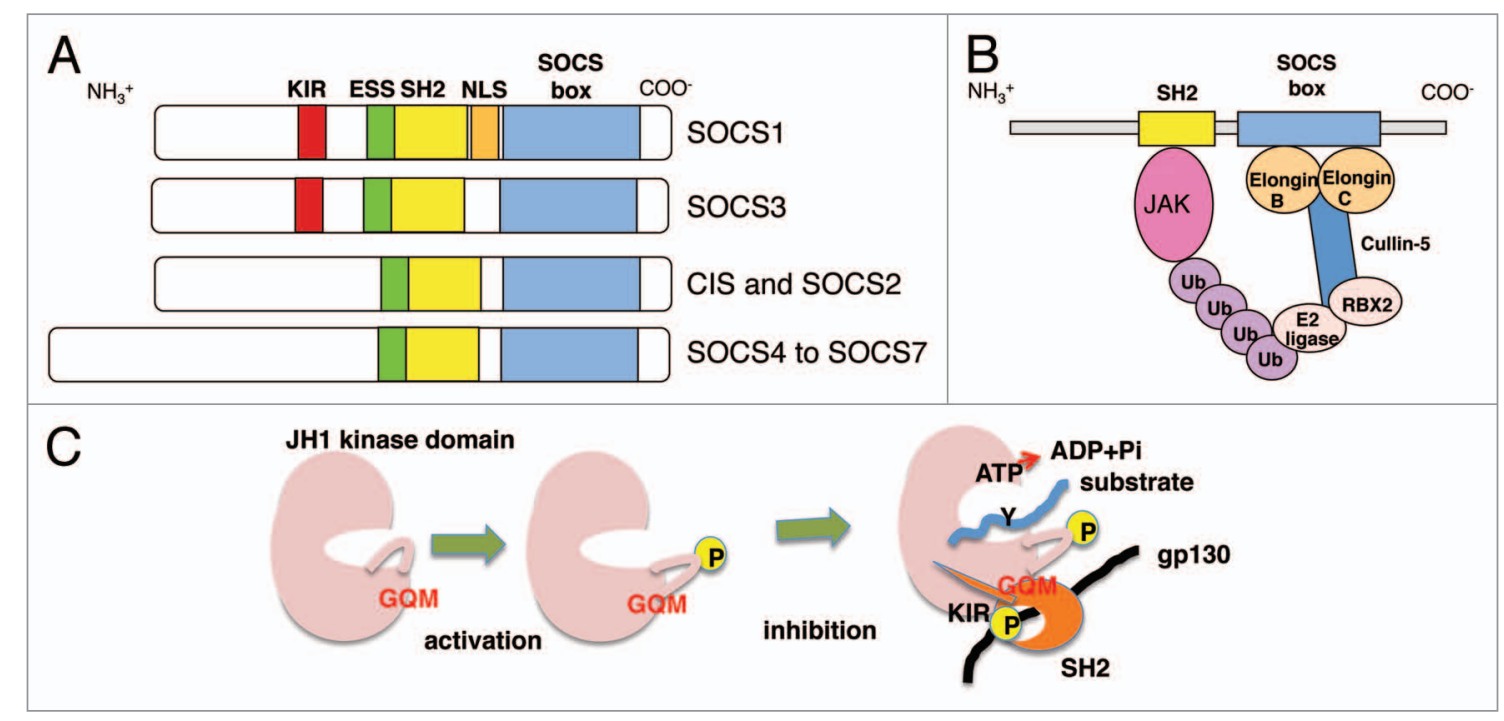

Figure 2. The structure and function of SOCS proteins. (A) The SOCS family consists of eight family members. All eight members share a central SH2 domain, extended SH2 domain (ESS), and a C-terminal SOCS box. In addition, SOCS1 and SOCS3 possess a kinase inhibitory region (KIR) that serves as a pseudo-substrate for JAKs, blocking JAK function. Only SOCS1 contains NLS. (B) A diagram of the extended interactions of SOCS with target proteins. The SOCS box interacts with several ubiquitinating machinery enzymes i.e., Elongin B, Elongin C, Cullin-5 (Cul5), and Ring-box 2 (Rbx2), and an E2 ubiquitin transferase. (C) New model of the inhibition of JAKs by SOCS3. This figure is modified from reference 23.

SOCS3 so that SOCS3 can bind to the surface of the JH1 kinase domain, including the GQM motif. Kinetic experiments showed that SOCS3 is a non-competitive inhibitor of JAK2-JH1, and SOCS3 specifically inhibits the ability of JH1 to transfer phosphate to tyrosine but does not inhibit its ability to hydrolyze ATP, thus increasing the transfer of phosphate to water ${ }^{22}$ (Fig. 2C). It remains to be elucidated whether SOCS1 inhibits JAK kinase by the same strategy. ${ }^{23}$

\section{Function of SOCS Proteins for Signaling Other than Cytokines: TLR Signaling and Nuclear Function}

In addition to the JAK-STAT signaling pathway, SOCS proteins, in particular SOCS1 and SOCS3, inhibit TLR signaling through MAL (myeloid differentiation primary-response gene 88 [MyD88]-adaptor-like protein), TNF receptor-associated factor (TRAF) 3 and 6, and the downstream target, NFкB.,24,25 TAM (Tyro3/Ax/Mer) receptor signaling inhibits TLR-induced cytokine receptor signaling, which is induced by SOCS1 and SOCS3 ${ }^{25}$ SOCS1 has been shown to bind and inhibit molecules in the TLR signaling pathway, including IRAK and the p65 subunit of $\mathrm{NFKB}^{26}$ and tyrosine phosphorylated MAL. ${ }^{24}$ SOCS3 inhibits the activation of TRAF3 and TRAF $6^{25,27}$ and transforming growth factor- $\beta$ (TGF $\beta$ )-activated kinase 1 (TAK1), both of which are crucial for TLR- and IL-1-induced responses. ${ }^{27}$ However, there are conflicting reports that indicate a minimal effect of SOCS3 on TLR responses. ${ }^{28}$

Accumulating evidences shed light on the role of SOCS1 in the nuclear function beyond inhibition of IFN signaling. Termination of NFKB signaling is also observed in the absence of ІкB. As a possible mechanism, Strebovsky et al. demonstrated that SOCS1 limits the duration of NFKB signaling by decreasing p65 stability in the cell nucleus. ${ }^{29}$ Although SOCS1 and SOCS3 share the same principal structure, ${ }^{17}$ only SOCS1 has a hitherto unknown nuclear localization sequence (NLS) located between the $\mathrm{SH} 2$ domain and SOCS box. ${ }^{30}$ These findings indicate that the SOCS1 can act from the vicinity of the receptor at the cell surface membrane to inhibit nuclear NFKB activity. In addition, SOCS1 can contribute to $\mathrm{p} 53$ phosphorylation and its activation, resulting in promotion of the $\mathrm{p} 53$-dependent process in the oncogene-induced cell. ${ }^{31}$

\section{socs in Tumors}

The correlation between inflammation and cancer is related to two pathways: an extrinsic pathway, which is driven by inflammation that increases cancer risk and an intrinsic pathway, which is driven by genetic alterations that cause inflammation and neoplasia. STATs and NFKB are key coordinators of innate immunity and inflammation and are executors of tumor promoters. ${ }^{32}$ Thus, SOCS is involved in tumor development by regulating STATs. Lesina et al. reported that IL-6 trans-signaling-dependent activation of STAT3/SOCS3 is required to promote progression of pancreatic intraepithelial neoplasias (PanINs) and pancreatic ductal adenocarcinoma (PDAC) that carry the Kras (G12D) mutaion..$^{33}$ The myeloid compartment induces STAT3 activation in tumor cells by secreting IL-6, essential in PanIN progression and PDAC development. Aberrant activation of STAT3, through homozygous deletion of SOCS3 in the pancreas, accelerates PanIN progression and PDAC development. This is a typical example of inflammatory cells-tumor interaction thorough the tumor-promoting cytokine, IL-6. However, these functions in tumor cells are highly dependent on tumor types and cell types. 
Expression of SOCS in human tumors. Decreased SOCS1 expression is observed in various cancers, including prostate cancer, HCCs, laryngeal carcinoma, multiple myeloma, acute myeloid leukemia, and pancreatic cancer and lymphoma. ${ }^{34,35}$ In prostate cancer, reduced SOCS1 expression is detected after androgen ablation and is elevated in recurrent patients. ${ }^{36}$ Thus, SOCS1 expression is affected by the tumor microenvironment, such as cytokines and hormone. On the other hand, higher expression of SOCS1 mRNA is associated with earlier tumor stages and better clinical outcomes in breast cancer. ${ }^{37}$ SOCS1 expression is higher in IFN-resistant tumor cells $s^{38}$ and siRNA inhibition of SOCS1 expression enhances the IFN-responsiveness, ${ }^{39}$ suggesting that SOCS1 overexpression is associated with disease progression. Although these discrepancies regarding SOCS1 expression in different cancers remains unknown, the higher level of SOCS1 expression is due to the onset of inflammatory responses; for example, in breast tumor tissues that are associated with inflammatory stroma cells, but not in breast cancer cell lines, may be caused by induction of SOCS1 expression by inflammatory cytokines, growth hormone, and prolactin in the tumor microenvironment. ${ }^{40}$

Persistent STAT3 activation is observed in many cancer cells, including head and neck cancer, ${ }^{41}$ colorectal cancer, HCCs, ${ }^{42}$ prostate cancer, renal cell carcinoma, ovary cancer, ${ }^{43}$ breast cancer, and leukemia. ${ }^{44}$ Reduced SOCS3 expression levels are detected in cancerous lesions infected with HCV compared with non-cancerous legions. ${ }^{6}$ Hyperactivation of STAT3 by reduced SOCS3 expression may contribute to malignancies and carcinogenesis by inducing multiple tumor-promoting genes. ${ }^{5}$ Remission of SOCS3 expression causes constitutive STAT3 activation, ${ }^{32}$ which is considered to be important for linkage between inflammation and cancer.

Silencing of SOCS1 was frequently observed even in premalignant $\mathrm{HCV}$-infected patients. ${ }^{8}$ Liver injury is associated with hyperactivation of STAT1 and reduced activation of STAT3. ${ }^{6}$ Therefore, reduced expression of SOCS1 might enhance tissue injury and inflammation by hyperactivation of STAT1, promoting the turnover of epithelial cells and enhancing their susceptibility to oncogenesis. SOCS1 is important in the inhibition of inflammation-associated tumor development, which is supported by the recent finding that in mice with Socs1 deletion in any type of cells, except $\mathrm{T}$ and $\mathrm{B}$ cells in mice, led to chronic colitis and colon tumors. ${ }^{7}$ This study strongly suggests that the chronic activation of the IFN- $\gamma$-STAT1 pathway that occurs in the absence of SOCS1 causes colitis-induced colon tumors. Therefore, SOCS1 is a unique anti-oncogene that prevents carcinogenesis by suppressing chronic inflammation.

SOCS3 might also be involved in the development and progression of malignancies. Unlike SOCS1, SOCS3 expression levels were high in $\mathrm{HCV}$-infected non-tumor areas of patients with HCV. ${ }^{6}$ Huang et al. also reported that the levels of SOCS3 are elevated in patients infected with $\mathrm{HCV}$, as well as in chimpanzee models, ${ }^{93}$ suggesting that the activation of SOCS3 contributes to the defective hepatic response to IFN- $\gamma$ in the HCV-infected liver. However, reduced expression of SOCS3 has been observed in various human cancers and is associated with constitutive
STAT3 activation. Indeed, the levels of SOCS3 were inversely correlated with STAT3 activation in regions of human livers with and without HCC. The mechanism behind this observation is more easily explicable than that of SOCS1, because numerous studies have shown that hyperactivation of STAT3 can contribute to tumorigenesis by inducing multiple tumorpromoting genes.

Mutation, methylation, and SNPs. Möller's group identified a deletion mutation in the SOCS1 gene in a major subset of primary mediastinal B-cell lymphomas (PMBL) and in the PMBL line MedB-1, and a biallelic SOCS1 deletion in PMBL line, Karpas1106P. SOCS1 deletion resulted in retarded JAK2 degradation and sustained pY-JAK2 action, leading to enhanced DNA binding of pY-STAT5. These findings support the concept that when defective, tumor suppressor gene SOCS1 triggers an oncogenic pathway operative in both lymphomas. ${ }^{45}$ Epigenetic inactivation of SOCS1 has also been found in cells from MDS patients carrying the JAK2 (Val617Phe) mutation. ${ }^{46}$

Decreased SOCS1 gene expression could be a mechanism involved in promoter hypermethylation. The hypermethylation of the SOCS1 promoter is detected in various cancers, including about $50 \%$ of hepatoblastoma, ${ }^{47}$ hepatocellular carcinoma, pancreatic cancers, ${ }^{32,35}$ more than $50 \%$ of melanoma, ${ }^{48}$ acute myeloid leukemia, multiple myeloma, and less than $50 \%$ of ovarian cancer, gastric cancer and breast cancer. ${ }^{35,49}$ DNA hypermethylation of SOCS1 is also frequently found in certain types of lymphomas and myelodysplastic syndrome (MDS), which may result in enhanced JAK2 activity that promotes cell proliferation. ${ }^{50,51}$ In these cases, the silencing of SOCS1 leads to the dysregulation of JAK-STAT signal transduction and therefore, contributes to growth factor hypersensitivity. On the other hand, the expression of SOCS1 in breast cancer tissue has been reported to be higher than that in corresponding normal tissue..$^{40}$ In melanoma cells, higher levels of SOCS1 are observed than in their normal cells. ${ }^{52}$ This evidence shows the need to identify the relationship between SOCS1 methylation and other genes that show clinical characteristics in cancer, although SOCS1 hypermethylation is common in carcinogenesis. Recently, $\mathrm{CpG}$ island methylator phenotype (CIMP) analysis has been considered to have more clinical value as a biomarker than a single gene methylation to detect and assess cancers. ${ }^{53}$ The combination analysis between SOCS1 hypermethylation and other gene markers, such as P16 (cyclin-dependent kinase 4 inhibitor), CDH1 (E-cadherin), and GSTP1 (glutathione S-transferase P), which have been demonstrated to frequently be methylated in various malignancies, has been performed to further define the prognostic value of SOCS1 in various tumors. ${ }^{54}$ This approach with its high sensitivity and specificity, will help identify good biomarkers of cancers.

SOCS3 has also been considered a tumor suppressor that is found in downregulation. Hypermethylation of the SOCS3 promoter is mostly found in $90 \%$ of head and neck cancer, ${ }^{55,56}$ followed by lung cancer, ${ }^{57}$ prostate cancer,${ }^{58}$ Barrett esophagus carcinoma $^{59}$ and ulcerative colitis-related colorectal cancer. ${ }^{60,61}$ These reports suggest that methylation-induced inactivation of the SOCS3 gene may be an early event in these cancers. However, melanoma cells constitutively express high levels of 
SOCS3, indicative of a tumor-protecting function. ${ }^{62}$ In breast cancer, decreased SOCS3 was not correlated with progression of lymph node metastasis, ${ }^{63}$ although SOCS1, SOCS3, and CIS were expressed at higher levels in carcinoma than normal mammary cells. ${ }^{64,65}$ Thus, the relationship among hypermethylation of SOCS1 and SOCS3 genes, real mRNA levels, and importantly, protein levels should be clarified in tumor cells.

A single nucleotide polymorphism (SNP), which is a variation at a single site in DNA, is the most frequent type of genomic variation. Tumor suppressor genes prevent tumor from development; however, one mutated or dysfunctional copy of a tumor suppressor gene can result in tumor development. Several genomic SNPs, within the locus of SOCS1 and/or STAT1, are associated with leukemia ${ }^{66}$ and colorectal cancer. ${ }^{67}$ SOCS1 mutations have been found in human lymphomas. ${ }^{34}$ In contrast, SNPs in SOCS3 have not been detected so far, ${ }^{68}$ although STAT3 SNPs are observed in cancer tissues. ${ }^{69}$ SNPs analysis is a new and valuable technique but still needs validation from additional independent studies before it can be used as a cancer detection strategies.

Mechanism of tumorigenesis by SOCS1 and SOCS3 deletion. In mouse models, SOCS1 and SOCS3 deletions in tumor cells are usually associated with hyperactivation of STAT1 and STAT3. STAT1 is widely considered a tumor suppressor, due to its ability to modulate apoptosis in a transcriptional mechanismdependent or -independent mechanism. SOCS1 ${ }^{-1-}$ mice develop spontaneous colorectal cancer, ${ }^{7}$ the development of which is strongly dependent on the IFN $\gamma$-STAT1 pathway. We suspect that NOS and PGE2 are highly upregulated by SOCS1 deficiency and that STAT1 hyperactivation is involved in tumorigenesis.

STAT3 is considered to be cell cycle-promoting and antiapoptosis. Potential target genes of STAT3 are cell survival genes, including $\mathrm{Bcl}-2$ and $\mathrm{Bcl}-\mathrm{xL}$, and cell cycle regulators, such as cyclin D1, cyclin E1, and p21. Transcription factors c-myc, c-jun, and $\mathrm{c}$-fos are also STAT3 targets. $^{70}$ In angiogenesis, VEGF is a target of STAT3, and TGF- $\beta$ contributes to tumor angiogenesis and fibrosis. ${ }^{71}$ TIMP-1, which inhibits matrix metalloproteinases and (MMPs), that are possibly involved in tissue remodeling, is another important target of STAT3. ${ }^{72}$ STAT3 may be involved in suppression of $\mathrm{p} 53$ expression $^{73}$ and $\mathrm{p} 21$, a p53 target gene. ${ }^{74}$

Cancer cells display upregulation of growth and survival pathway, which are regulated by autocrine production of growth and survival factors. Very recently, by generating mice with SOCS3 deletion in gastrointestinal epithelial cell (T3b-SOCS3 cKO mice), we demonstrated that aberrant leptin signaling, which is transduced by the JAK-STAT pathway, causes gastric cancer. ${ }^{3}$ The leptin receptor $(\mathrm{ObR})$ is considerably similar to gp130, and its signaling is transduced by JAK2-STAT3 and inhibited by SOCS3. ${ }^{18}$ T3b-SOCS3 cKO mice may have a more severe tumor phenotype (100\% mortality within 6 mo of birth) than gp130 $1757 \mathrm{~F}$ mice. ${ }^{75}$ We presume that since leptin signaling is suppressed by SOCS3 in gp130 ${ }^{\mathrm{Y} 757 \mathrm{~F}}$ mice, which have a mutated form of gp130 that cannot bind to SOCS3, abrogated SHP-2-ERK, and enhancement of the STAT3 pathway, neither gp130 nor ObR signaling is inhibited in T3b-SOCS3 cKO mice. Because cancer may be a stem cell-based disease and upregulation of leptin signaling is seen in cancerous tissues, such as stomach and mammary, our study can shed light on the mechanism of initiation of carcinogenesis mediated by leptin-SOCS3 signaling. It has been reported that tumorinitiating stem cells potently express ObR, thereby promoting tumorigenesis by STAT3 activation and inducing pluripotencyassociated transcription factors, such as oct 4 and sox $2,{ }^{76}$ suggesting that leptin is strongly involved in initiation of tumorigenesis. Leptin has been shown to act in stage of tumor progression but not in tumor initiation in variety tumor model such as colorectal $^{77}$ and breast cancer. ${ }^{78}$ These evidences may implicate that leptin actively affects both steps of tumor initiation and progression through STAT3 activation, although further studies are necessary to prove this hypothesis. In regard to the bowels, intestinal EC-specific SOCS3-deficient mice (villin-SOCS3 cKO mice) do not show any spontaneous phenotype, despite STAT3 being activated. ${ }^{79}$ The factors that determine tissue-specific effects of SOCS3 deficiency on oncogenesis remain an open question.

\section{SOCS-Mediated Interplay between Inflammation and Cancer}

SOCS and inflammation-associated cancer. In 1863, Rudolf Virchow identified the presence of leukocytes presence within cancerous tissue. This finding provides the first connection between inflammation and cancer. ${ }^{80}$ Presently, infections and inflammatory responses are linked to an estimated $15-20 \%$ of all deaths from cancer worldwide. Triggers of chronic inflammation, which are a risk factor of carcinogenesis, include three categories: (1) microbial infections, such as Helicobacter pylori and hepatitis $C$ virus, which are associated with gastric cancer and hepatocellular carcinomas (HCCs), respectively, ${ }^{81,82}$ (2) autoimmune diseases, such as inflammatory bowel diseases, which is associated with colon cancer, and (3) inflammation of an unknown origin, such as prostasis, which is associated with prostate cancer. ${ }^{83}$ Villin-SOCS3 cKO mice are susceptible to challenge with azoxymethane (AOM) plus dextran sodium sulfate (DSS) to develop colonic tumor, ${ }^{79}$ although these mice show no phenotype without the challenge; conversely, villin-STAT3 KO mice are resistant to the challenge. ${ }^{84}$ These evidences clearly indicate that STAT3-dependent inflammation triggered tumor promotion. Gastric cancer and colorectal cancer are caused by persistent inflammatory responses in tissue mucosa. Furthermore, treatment with nonsteroidal anti-inflammatory agents reduces incidence and mortality significantly in various cancers, including prostate, breast, and colon. ${ }^{85}$ Thus, these studies highlight the links between inflammation and cancer and suggest that the immune factors that promote oncogenesis may represent viable therapeutic targets.

A series of studies using gp130 $13757 \mathrm{~F}$ mutant mice provided the critical mechanism of involvement of gp130 in the development of inflammation-associated gastric cancer, due to IL-11-driven activation of STAT1 and STAT $3 .{ }^{86}$ In humans, $60 \%$ of inflammatory hepatocellular adenomas are associated with in-frame somatic mutations in gp130. ${ }^{87}$ In addition to aberrant SOCS3 expression, the loss of SOCS3 function, such as that resulting from a gp130 mutation, is important for understanding inflammation-associated cancer. 
SOCS mediates cancer-associated inflammation. As described above, in some types of cancer, inflammation precedes malignant changes. On the other hand, oncogene-driven signals activate intrinsic pro-inflammatory pathways, resulting in an inflammatory microenvironment that further promotes cancer development. ${ }^{88,89}$ Growing tumors can disrupt epithelial barrier function, the tissue architecture, and the extracellular matrix. These processes may stimulate steps of tissue repair, including the recruitment of inflammatory cells. These responses lead to tumor growth itself, promoting a positive feedback loop of tumorigenesis.

A recent report indicates that STAT3 activation correlates with TLR2 upregulation, which is necessary to promote gastric tumorigenesis. ${ }^{90}$ gp130 ${ }^{\mathrm{Y} 757 \mathrm{~F}}$ mice, in which the mutated gp130 cannot bind to SOCS3, spontaneously develop gastric tumors. However, gp130 ${ }^{\mathrm{Y} 757 \mathrm{~F}}$ mice that lack TLR2 (gp130 ${ }^{\mathrm{Y} 757 \mathrm{~F}}$ : TLR2 ${ }^{-/-}$) show improved gastric lesions compared with gp130 ${ }^{\mathrm{Y} 757 \mathrm{~F}}$ mice, even with no difference in inflammatory observation between these mice. The expression status and causal role of TLRs in human gastric cancer remain unclear, although TLR2 and TLR4 gene polymorphisms are associated with an increased risk for developing gastric cancer. ${ }^{91,92}$ Thus, TLR is an important additional factor in inflammation-associated carcinogenesis. T3b-SOCS3 cKO mice, which show aberrant activation of leptin signaling and gp130, exhibit gastric cancer with no inflammatory response during the initiation step of carcinogenesis, whereas gastritis precedes tumor formation in gp130 ${ }^{\mathrm{Y} 757 \mathrm{~F}}$ mice. ${ }^{75}$ This evidence indicates that additive factor, such as TLR and hormone signaling, are necessary for STAT3-driven carcinogenesis.

Role of SOCS in tumor-associated macrophages and dendritic cells. As the most potent antigen presenting cells (APCs) in vivo, dendritic cells (DCs) induce innate and adaptive immunity and are considered as targets in anti-tumor immunity. ${ }^{94,95}$ Immunization with SOCS1 ${ }^{-/-}$DCs induces a hyper Th1 immune responses, lupus-like autoimmune disease, and anti-tumor activities. ${ }^{96}$ Another APC, macrophages (M $\left.\phi\right)$ are also the effector cells in anti-tumor immunity, ${ }^{10}$ in addition to playing a similar role as DCs. This evidence suggests that SOCS1 is a constitutive antigen presentation repressor in APCs and a critical switch in M申 balance. $\mathrm{Gr}^{+} \mathrm{CD} 11^{+}$myeloid-derived suppressor cells reportedly play a role in suppressing anti-tumor immunity in tumors and promote tumor growth. ${ }^{97}$ Expansion of these cells is accelerated by phosphorylated STAT3.$^{98}$ Conventional M $\phi$ do not show such activities. It may be critical in the treatment of cancer to regulate the balance between both immunity for suppression of cancer promotion and activation of anticancer molecules.

$\mathrm{M} \phi$ are activated by various environmental factors and develop polarized functions: classically activated M $\phi$ (M1) eliminate pathogens but can cause tissue injury and alternatively activated (M2) M $\phi$, which promote healing and repair. Recent work demonstrates that M2 M $\phi$ show a selective and IL-4-dependent upregulation of SOCS1 but not SOCS3. ${ }^{99}$ SOCS3 in macrophages may regulate $\mathrm{M} \phi$ polarization. $\mathrm{M} \phi$ in which SOCS3 was knocked down by short interfering RNA (siRNA) prevented M1 $\mathrm{M} \phi$ activation, suggesting that SOCS3 is necessary for M1 M $\phi .^{57}$ Wang et al. reported that forced activation of Notch signaling in $\mathrm{M} \phi$ enhanced M1 polarization and their anti-tumor capacity through SOCS3 induction. ${ }^{100} \mathrm{M} \phi$-specific SOCS3-cKO mice exhibited resistance to the tumor transplantation model because of reduced tumor-promoting cytokines, such as TNF $\alpha$ and IL-6, and enhanced production of the anti-tumorigenic chemokine MCP2/CCL8. ${ }^{101}$ Recently, Spence et al. reported ${ }^{102}$ that SOCS3deficeincy in macrophages skewed M2-like polarization, while SOCS1 deficiency induced M1-like phenotypes. Interestingly, in the LPS response, enhanced regulatory $\mathrm{T}$ (Treg) cell recruitment was observed in SOCS3-deficient M $\phi$, whereas Treg cell recruitment was absent in the absence of SOCS3. The authors of the study suggested that SOCS3 in M $\phi$ suppressed M2 by inhibiting IL-4- and IL-12-induced STAT6 phosphorylation. SOCS, therefore, are essential controllers of macrophage polarization, regulating inflammatory responses.

\section{Therapeutic Implications}

The use of SOCS proteins to suppress cytokine signaling could be a useful therapy for the treatment of cancer. There are several approaches. One approach is the overexpression of SOCS proteins to inhibit tumor growth by suppressing tumor-promoting STATs. The second method is enhancing anti-tumor immunity by silencing of SOCS in dendritic cells or CTLs. ${ }^{35}$

We showed that overexpression of SOCS1 can induce apoptosis of leukemic cells constitutively expressing activated JAK2. ${ }^{16}$ Adenovirus-mediated overexpression of SOCS1 can prevent HPV-related cells transformation by inducing degradation of the E7 oncoprotein. ' SOCS1 overexpression inhibits in vitro and in vivo expansion of human melanoma cells, and SOCS1 associates specifically with Cdh1, triggering its degradation by the proteasome. ${ }^{103}$ Enforced expression of SOCS1 leads to be resistant to transformation due to oncogenic induction. ${ }^{104}$ SOCS3 overexpression also inhibits growth of nonsmall lung cancer cells. ${ }^{105}$ SOCS3 overexpression by adenoviral transfer enhanced the radio-sensitivity of treated non-small lung cancer cells. Infection of cells with oncolytic adenovirus CN305 (AdCN305)-SOCS3 and AdCN305-cell-penetrating peptides-SOCS3 (membrane permeable SOCS3) resulted in dramatic cytotoxicity of liver tumor cells. However, no cytotoxic effect was observed in normal cells infected with these vectors. Infection of liver tumor cells with AdCN305-SOCS3 and AdCN305-cpp-SOCS3 resulted in nearly complete inhibition of STAT3 phosphorylation and downregulation of cyclin D1 and Bcl-xL. This study suggests that transfer of SOCS3 by an oncolytic adenovirus represents a potent approach for cancer therapy. ${ }^{106}$ SOCS3 overexpression suppressed growth of malignant fibrous histiocytoma cell lines by inhibiting STAT3 and IL- 6 production. In addition, this study raised the possibility that small molecule inhibitors of JAK-STAT could be therapeutic for IL- 6 producing tumors. ${ }^{107}$ The tyrosine kinase inhibitor peptide, Tkip, was developed as a mimetic of SOCS proteins and effectively inhibits JAK2-mediated phosphorylation of STAT1: this peptide inhibited proliferation of prostate cancer cell lines, in which STAT3 is constitutively activated. ${ }^{108}$ Upregulation of SOCS3 by some reagents may also be therapeutic. Recently, 
platelet factor- 4 was found to induce SOCS3, thereby suppressing STAT3 activation, angiogenesis, and growth and inducing apoptosis of myeloma cells. ${ }^{109}$

Downregulation of SOCS gene expression by siRNA or by the expression of dominantnegative SOCS proteins to enhance cytokine signaling may be useful for enhancing antitumor immunity. The treatment of DCs with SOCS1 siRNA significantly enhanced the ability of DC-based tumor vaccines to break selftolerance and to induce effective anti-tumor immunity. ${ }^{35,110,111}$ We have shown that adoptive transfer of SOCS1-deficient T cells strongly regressed transplanted tumor cells (Takahashi and Yoshimura, unpublished data).

All these studies are encouraging for the clinical application of novel therapeutic approaches to mimic or modulate expression and function of SOCS proteins (Fig. 3).

\section{Concluding Remarks}

Over the past decade, following the discovery of the SOCS protein family, we have extended our understanding of the structure and function of SOCS proteins. Regarding cancer development, SOCS1 and SOCS3 are tightly linked to cancer cell proliferation, as well as cancer-associated inflammation. In most cases, SOCS1 and SOCS3 silencing promoted carcinogenesis at various stages; thus, overexpression of SOCS1 and SOCS3 or SOCSmimetics can be a therapuetic treatment. However, SOCS1 in DCs and likely $\mathrm{T}$ cells suppresses anti-tumor immunity; therefore, silencing SOCS1 in these cells could be therapeutic. Development of SOCS, based on structural analysis of the JAK/ SOCS complex, is highly desirable.

\section{References}

1. Endo TA, Masuhara M, Yokouchi M, Suzuki R, Sakamoto H, Mitsui K, et al. A new protein containing an SH2 domain that inhibits JAK kinases. Nature 1997; 387:921-4; PMID:9202126; http://dx.doi. org/10.1038/43213

2. Yoshimura A, Naka T, Kubo M. SOCS proteins, cytokine signalling and immune regulation. Nat Rev Immunol 2007; 7:454-65; PMID:17525754; http:// dx.doi.org/10.1038/nri2093

3. Inagaki-Ohara K, Mayuzumi H, Kato S, Minokoshi Y, Otsubo T, Kawamura YI, et al. Enhancement of leptin receptor signaling by SOCS3 deficiency induces development of gastric tumors in mice. Oncogene 2012; In press; PMID:23178499; http://dx.doi.org/10.1038/ onc. 2012.540

4. Inagaki-Ohara K, Sasaki A, Matsuzaki G, Ikeda T, Hotokezaka M, Chijiiwa K, et al. Suppressor of cytokine signalling 1 in lymphocytes regulates the development of intestinal inflammation in mice. Gut 2006; 55:212-9; PMID:16120757; http://dx.doi. org/10.1136/gut.2004.062653

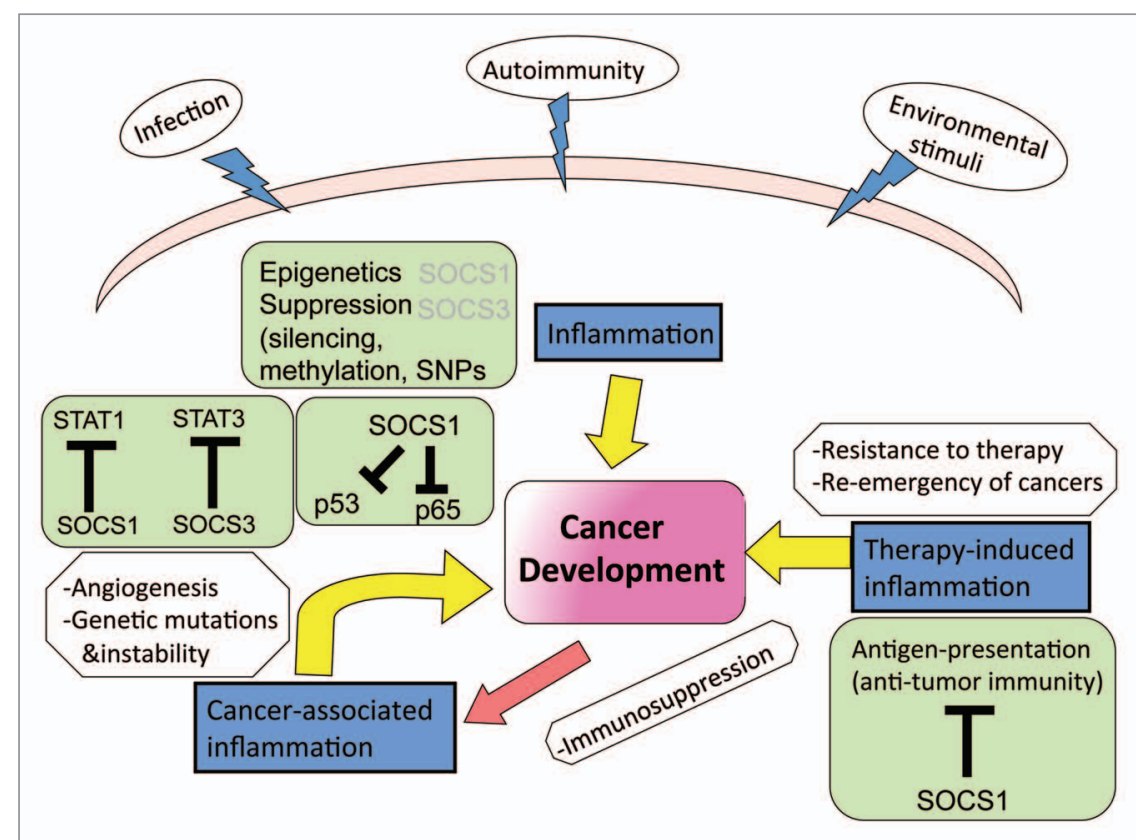

Figure 3. Types and relationships between inflammation and cancer. Chronic inflammation by infections, autoimmune disease, and prolonged exposure to environmental factors precedes tumor development and can contribute to induce oncogenic mutations, genomic instability, early tumor promotion, and enhanced angiogenesis. Tumor-associated inflammation amplifies cancer development. Cancer therapy can also trigger an inflammatory response by causing trauma, necrosis, and tissue injury that stimulate tumor re-emergence and resistance to therapy. However, in some cases, therapy-induced inflammation can enhance antigen presentation, leading to immunomediated tumor eradication, in which SOCS1 plays a role through enhancement of anti-tumor immunity.

\section{Disclosure of Potential Conflicts of Interest}

No potential conflicts of interest were disclosed.

\section{Acknowledgments}

$\mathrm{KIO}$ is supported by Grants-in-Aid for Scientific Research (C) from the Ministry of Education, Culture, Sports, Science and Technology of Japan (23590272).
5. Ogata H, Chinen T, Yoshida T, Kinjyo I, Takaesu $\mathrm{G}$, Shiraishi H, et al. Loss of SOCS3 in the liver promotes fibrosis by enhancing STAT3-mediated TGF-beta1 production. Oncogene 2006; 25:252030; PMID:16474852; http://dx.doi.org/10.1038/ sj.onc. 1209281

6. Ogata H, Kobayashi T, Chinen T, Takaki H, Sanada T, Minoda Y, et al. Deletion of the SOCS3 gene in liver parenchymal cells promotes hepatitis-induced hepatocarcinogenesis. Gastroenterology 2006; 131:179-93; PMID:16831601; http://dx.doi.org/10.1053/j.gastro.2006.04.025

7. Hanada T, Kobayashi T, Chinen T, Saeki K, Takaki $\mathrm{H}$, Koga $\mathrm{K}$, et al. IFNgamma-dependent, spontaneous development of colorectal carcinomas in SOCS1-deficient mice. J Exp Med 2006; 203:13917; PMID:16717119; http://dx.doi.org/10.1084/ jem.20060436

8. Yoshida T, Ogata H, Kamio M, Joo A, Shiraishi H, Tokunaga Y, et al. SOCS1 is a suppressor of liver fibrosis and hepatitis-induced carcinogenesis. J Exp Med 2004; 199:1701-7; PMID:15197228; http://dx.doi. org/10.1084/jem.20031675
9. Kamio M, Yoshida T, Ogata H, Douchi T, Nagata $\mathrm{Y}$, Inoue M, et al. SOCS1 [corrected] inhibits HPVE7-mediated transformation by inducing degradation of E7 protein. Oncogene 2004; 23:3107-15; PMID:15021916; http://dx.doi.org/10.1038/ sj.onc. 1207453

10. Hashimoto M, Ayada T, Kinjyo I, Hiwatashi K, Yoshida H, Okada Y, et al. Silencing of SOCS1 in macrophages suppresses tumor development by enhancing antitumor inflammation. Cancer Sci 2009; 100:730-6; PMID:19469017; http://dx.doi.org/10.1111/j.13497006.2009.01098.x

11. Hanahan D, Weinberg RA. The hallmarks of cancer. Cell 2000; 100:57-70; PMID:10647931; http:// dx.doi.org/10.1016/S0092-8674(00)81683-9

12. Kinzler KW, Vogelstein B. Lessons from hereditary colorectal cancer. Cell 1996; 87:159-70; PMID:8861899; http://dx.doi.org/10.1016/S00928674(00)81333-1

13. O'Shea JJ, Gadina M, Schreiber RD. Cytokine signaling in 2002: new surprises in the Jak/Stat pathway. Cell 2002; 109(Suppl):S121-31; PMID:11983158; http:// dx.doi.org/10.1016/S0092-8674(02)00701-8 
14. Yasukawa H, Sasaki A, Yoshimura A. Negative regulation of cytokine signaling pathways. Annu Rev Immunol 2000; 18:143-64; PMID:10837055; http:// dx.doi.org/10.1146/annurev.immunol.18.1.143

15. Piessevaux J, Lavens D, Peelman F, Tavernier J. The many faces of the SOCS box. Cytokine Growth Factor Rev 2008; 19:371-81; PMID:18948053; http://dx.doi. org/10.1016/j.cytogfr.2008.08.006

16. Yoshimura A, Suzuki M, Sakaguchi R, Hanada T, Yasukawa H. SOCS, Inflammation, and Autoimmunity. Front Immunol 2012; 3:20; PMID:22566904; http:// dx.doi.org/10.3389/fimmu.2012.00020

17. Yoshimura A, Naka T, Kubo M. SOCS proteins, cytokine signalling and immune regulation. Nat Rev Immunol 2007; 7:454-65; PMID:17525754; http:// dx.doi.org/10.1038/nri2093

18. La Cava A, Matarese G. The weight of leptin in immunity. Nat Rev Immunol 2004; 4:371-9; PMID:15122202; http://dx.doi.org/10.1038/nri1350

19. Yasukawa $H$, Misawa $H$, Sakamoto $H$, Masuhara M, Sasaki A, Wakioka T, et al. The JAK-binding protein $\mathrm{JAB}$ inhibits Janus tyrosine kinase activity through binding in the activation loop. EMBO J 1999; 18:1309-20; PMID:10064597; http://dx.doi. org/10.1093/emboj/18.5.1309

20. Starr R, Fuchsberger M, Lau LS, Uldrich AP, Goradia A, Willson TA, et al. SOCS-1 binding to tyrosine 441 of IFN-gamma receptor subunit 1 contributes to the attenuation of IFN-gamma signaling in vivo. J Immunol 2009; 183:4537-44; PMID:19734231; http://dx.doi.org/10.4049/jimmunol.0901010

21. Qing Y, Costa-Pereira AP, Watling D, Stark GR. Role of tyrosine 441 of interferon-gamma receptor subunit 1 in SOCS-1-mediated attenuation of STAT1 activation. J Biol Chem 2005; 280:1849-53; PMID:15522878; http://dx.doi.org/10.1074/jbc.M409863200

22. Babon JJ, Kershaw NJ, Murphy JM, Varghese LN, Laktyushin A, Young SN, et al. Suppression of cytokine signaling by SOCS3: characterization of the mode of inhibition and the basis of its specificity. Immunity 2012; 36:239-50; PMID:22342841; http://dx.doi. org/10.1016/j.immuni.2011.12.015

23. Yoshimura A, Yasukawa H. JAK's SOCS: a mechanism of inhibition. Immunity 2012; 36:157-9; PMID:22365659; http://dx.doi.org/10.1016/j.immuni.2012.01.010

24. Mansell A, Smith R, Doyle SL, Gray P, Fenner JE, Crack PJ, et al. Suppressor of cytokine signaling 1 negatively regulates Toll-like receptor signaling by mediating Mal degradation. Nat Immunol 2006; 7:148-55; PMID:16415872; http://dx.doi.org/10.1038/ni1299

25. Rothlin CV, Ghosh S, Zuniga EI, Oldstone MB, Lemke G. TAM receptors are pleiotropic inhibitors of the innate immune response. Cell 2007; 131:112436; PMID:18083102; http://dx.doi.org/10.1016/j. cell.2007.10.034

26. Nakagawa R, Naka T, Tsutsui H, Fujimoto M, Kimura A, Abe T, et al. SOCS-1 participates in negative regulation of LPS responses. Immunity 2002; 17:677-87; PMID:12433373; http://dx.doi.org/10.1016/S10747613(02)00449-1

27. Frobøse H, Rønn SG, Heding PE, Mendoza H, Cohen P, Mandrup-Poulsen T, et al. Suppressor of cytokine Signaling-3 inhibits interleukin-1 signaling by targeting the TRAF-6/TAK1 complex. Mol Endocrinol 2006; 20:1587-96; PMID:16543409; http://dx.doi. org/10.1210/me.2005-0301

28. Prêle CM, Keith-Magee AL, Yerkovich ST, Murcha M, Hart PH. Suppressor of cytokine signalling-3 at pathological levels does not regulate lipopolysaccharide or interleukin-10 control of tumour necrosis factoralpha production by human monocytes. Immunology 2006; 119:8-17; PMID:16925527; http://dx.doi. org/10.1111/j.1365-2567.2006.02383.x

29. Strebovsky J, Walker P, Lang R, Dalpke AH. Suppressor of cytokine signaling 1 (SOCS1) limits NFkappaB signaling by decreasing p65 stability within the cell nucleus. FASEB J 2011; 25:863-74; PMID:21084693; http://dx.doi.org/10.1096/fj.10-170597
30. Baetz A, Koelsche C, Strebovsky J, Heeg K, Dalpke $\mathrm{AH}$. Identification of a nuclear localization signal in suppressor of cytokine signaling 1. FASEB J 2008; 22:4296-305; PMID:18725457; http://dx.doi. org/10.1096/fj.08-116079

31. Calabrese V, Mallette FA, Deschênes-Simard X, Ramanathan S, Gagnon J, Moores A, et al. SOCS1 links cytokine signaling to $\mathrm{p} 53$ and senescence. Mo Cell 2009; 36:754-67; PMID:20005840; http:// dx.doi.org/10.1016/j.molcel.2009.09.044

32. Yoshimura A. Signal transduction of inflammatory cytokines and tumor development. Cancer Sci 2006; 97:439-47; PMID:16734720; http://dx.doi. org/10.1111/j.1349-7006.2006.00197.x

33. Lesina M, Kurkowski MU, Ludes K, Rose-John S, Treiber M, Klöppel G, et al. Stat3/Socs3 activation by IL- 6 transsignaling promotes progression of pancreatic intraepithelial neoplasia and development of pancreatic cancer. Cancer Cell 2011; 19:456 69; PMID:21481788; http://dx.doi.org/10.1016/j. ccr.2011.03.009

34. Mottok A, Renné C, Seifert M, Oppermann E, Bechstein W, Hansmann ML, et al. Inactivating SOCS 1 mutations are caused by aberrant somatic hypermutation and restricted to a subset of B-cell lymphoma entities. Blood 2009; 114:4503-6; PMID:19734449; http://dx.doi.org/10.1182/blood-2009-06-225839

35. Zhang J, Li H, Yu JP, Wang SE, Ren XB. Role of SOCS 1 in tumor progression and therapeutic application. Int J Cancer 2012; 130:1971-80; PMID:22025331; http:// dx.doi.org/10.1002/ijc. 27318

36. Neuwirt H, Puhr M, Santer FR, Susani M, Doppler W, Marcias G, et al. Suppressor of cytokine signal ing (SOCS)-1 is expressed in human prostate cance and exerts growth-inhibitory function through downregulation of cyclins and cyclin-dependent kinases. Am J Pathol 2009; 174:1921-30; PMID:19342366; http:// dx.doi.org/10.2353/ajpath.2009.080751

37. Sasi W, Jiang WG, Sharma A, Mokbel K. Higher expression levels of SOCS 1,3,4,7 are associated with earlier tumour stage and better clinical outcome in human breast cancer. BMC Cancer 2010; 10:178; PMID:20433750; http://dx.doi.org/10.1186/14712407-10-178

38. Zitzmann K, Brand S, De Toni EN, Baehs S, Göke B, Meinecke J, et al. SOCS1 silencing enhances antitumor activity of type I IFNs by regulating apoptosis in neuroendocrine tumor cells. Cancer Res 2007; 67:5025-32 PMID:17510435; http://dx.doi.org/10.1158/00085472.CAN-06-2575

39. Lesinski GB, Zimmerer JM, Kreiner M, Trefry J, Bill MA, Young GS, et al. Modulation of SOCS protein expression influences the interferon responsiveness of human melanoma cells. BMC Cancer 2010; 10:142; PMID:20398276; http://dx.doi.org/10.1186/14712407-10-142

40. Raccurt M, Tam SP, Lau P, Mertani HC, Lambert A Garcia-Caballero T, et al. Suppressor of cytokine signalling gene expression is elevated in breast carcinoma. $\mathrm{Br}$ J Cancer 2003; 89:524-32; PMID:12888825; http:// dx.doi.org/10.1038/sj.bjc.6601115

41. Leeman RJ, Lui VW, Grandis JR. STAT3 as a therapeutic target in head and neck cancer. Expert Opin Biol Ther 2006; 6:231-41; PMID:16503733; http://dx.doi. org/10.1517/14712598.6.3.231

42. Silver JS, Hunter CA. gp130 at the nexus of inflammation, autoimmunity, and cancer. J Leukoc Bio 2010; 88:1145-56; PMID:20610800; http://dx.doi. org/10.1189/jlb.0410217

43. Guo Y, Xu F, Lu T, Duan Z, Zhang Z. Interleukin-6 signaling pathway in targeted therapy for cancer. Cancer Treat Rev 2012; 38:904-10; PMID:22651903; http://dx.doi.org/10.1016/j.ctrv.2012.04.007

44. Yu H, Kortylewski M, Pardoll D. Crosstalk between cancer and immune cells: role of STAT3 in the tumou microenvironment. Nat Rev Immunol 2007; 7:41-51; PMID:17186030; http://dx.doi.org/10.1038/nri1995
45. Melzner I, Weniger MA, Bucur AJ, Brüderlein S Dorsch K, Hasel C, et al. Biallelic deletion within 16p13.13 including SOCS-1 in Karpas1106P mediastinal B-cell lymphoma line is associated with delayed degradation of JAK2 protein. Int J Cancer 2006; 118:1941-4; PMID:16287070; http://dx.doi. org/10.1002/ijc. 21485

46. Jost E, do O N, Dahl E, Maintz CE, Jousten P, Habets $\mathrm{L}$, et al. Epigenetic alterations complement mutation of JAK2 tyrosine kinase in patients with BCR ABL-negative myeloproliferative disorders. Leukemia 2007; 21:505-10; PMID:17230231; http://dx.doi. org/10.1038/sj.leu.2404513

47. Sakamoto LH, DE Camargo B, Cajaiba M, Soares FA, Vettore AL. MT1G hypermethylation: a potential prognostic marker for hepatoblastoma. Pediatr Res 2010; 67:387-93; PMID:20032811; http://dx.doi. org/10.1203/PDR.0b013e3181d01863

48. Liu S, Ren S, Howell P, Fodstad O, Riker AI. Identification of novel epigenetically modified genes in human melanoma via promoter methylation gene profiling. Pigment Cell Melanoma Res 2008; 21:545-58; PMID:18627528; http://dx.doi.org/10.1111/j.1755148X.2008.00484.x

49. Sutherland KD, Lindeman GJ, Choong DY, Wittlin S, Brentzell L, Phillips W, et al. Differential hypermethylation of SOCS genes in ovarian and breast carcinomas. Oncogene 2004; 23:7726-33; PMID:15361843; http://dx.doi.org/10.1038/sj.onc. 1207787

50. Weniger MA, Melzner I, Menz CK, Wegener S, Bucur AJ, Dorsch K, et al. Mutations of the tumor suppressor gene SOCS-1 in classical Hodgkin lymphoma are frequent and associated with nuclear phosphoSTAT5 accumulation. Oncogene 2006; 25:2679 84; PMID:16532038; http://dx.doi.org/10.1038/ sj.onc. 1209151

51. Melzner I, Bucur AJ, Brüderlein S, Dorsch K, Hasel C, Barth TF, et al. Biallelic mutation of SOCS-1 impairs JAK2 degradation and sustains phospho-JAK2 action in the MedB-1 mediastinal lymphoma line. Blood 2005; 105:2535-42; PMID:15572583; http://dx.doi. org/10.1182/blood-2004-09-3701

52. Li Z, Metze D, Nashan D, Müller-Tidow C, Serve HL, Poremba C, et al. Expression of SOCS-1, suppressor of cytokine signalling-1, in human melanoma. J Invest Dermatol 2004; 123:737-45; PMID:15373779; http:// dx.doi.org/10.1111/j.0022-202X.2004.23408.x

53. Tanemura A, Terando AM, Sim MS, van Hoese AQ, de Maat MF, Morton DL, et al. CpG island methylator phenotype predicts progression of malignant melanoma. Clin Cancer Res 2009; 15:1801-7; PMID:19223509; http://dx.doi.org/10.1158/1078 0432.CCR-08-1361

54. Wu LM, Zhang F, Zhou L, Yang Z, Xie HY, Zheng SS Predictive value of $\mathrm{CpG}$ island methylator phenotype for tumor recurrence in hepatitis B virus-associated hepatocellular carcinoma following liver transplantation. BMC Cancer 2010; 10:399; PMID:20678188; http://dx.doi.org/10.1186/1471-2407-10-399

55. He B, You L, Uematsu K, Zang K, Xu Z, Lee AY, et al. SOCS-3 is frequently silenced by hypermethylation and suppresses cell growth in human lung cancer. Proc Nat Acad Sci U S A 2003; 100:14133-8; PMID:14617776; http://dx.doi.org/10.1073/pnas.2232790100

56. Weber A, Hengge UR, Bardenheuer W, Tischoff I, Sommerer F, Markwarth A, et al. SOCS-3 is frequently methylated in head and neck squamous cell carcinoma and its precursor lesions and causes growth inhibition. Oncogene 2005; 24:6699-708; PMID:16007169; http://dx.doi.org/10.1038/sj.onc. 1208818

57. Liu WB, Ao L, Zhou ZY, Cui ZH, Zhou YH, Yuan $\mathrm{XY}$, et al. $\mathrm{CpG}$ island hypermethylation of multiple tumor suppressor genes associated with loss of their protein expression during rat lung carcinogenesis induced by 3-methylcholanthrene and diethylnitrosamine. Biochem Biophys Res Commun 2010; 402:50714; PMID:20970405; http://dx.doi.org/10.1016/j. bbrc.2010.10.061 
58. Pierconti F, Martini M, Pinto F, Cenci T, Capodimonti $\mathrm{S}$, Calarco A, et al. Epigenetic silencing of SOCS3 identifies a subset of prostate cancer with an aggressive behavior. Prostate 2011; 71:318-25; PMID:20717995; http://dx.doi.org/10.1002/pros.21245

59. Tischoff I, Hengge UR, Vieth M, Ell C, Stolte M, Weber A, et al. Methylation of SOCS-3 and SOCS-1 in the carcinogenesis of Barrett's adenocarcinoma. Gut 2007; 56:1047-53; PMID:17376806; http://dx.doi. org/10.1136/gut.2006.111633

60. Li Y, de Haar C, Chen M, Deuring J, Gerrits MM, Smits R, et al. Disease-related expression of the IL6/ STAT3/SOCS3 signalling pathway in ulcerative colitis and ulcerative colitis-related carcinogenesis. Gut 2010; 59:227-35; PMID:19926618; http://dx.doi. org/10.1136/gut.2009.184176

61. Li Y, Deuring J, Peppelenbosch MP, Kuipers EJ, de Haar C, van der Woude CJ. IL-6-induced DNMT1 activity mediates SOCS3 promoter hypermethylation in ulcerative colitis-related colorectal cancer Carcinogenesis 2012; 33:1889-96; PMID:22739025; http://dx.doi.org/10.1093/carcin/bgs214

62. Fojtova M, Boudny V, Kovarik A, Lauerova L, Adamkova L, Souckova K, et al. Development of IFN-gamma resistance is associated with attenuation of SOCS genes induction and constitutive expression of SOCS 3 in melanoma cells. Br J Cancer 2007; 97:2317; PMID:17579625; http://dx.doi.org/10.1038/ sj.bjc. 6603849

63. Nakagawa T, Iida $S$, Osanai T, Uetake H, Aruga T, Toriya Y, et al. Decreased expression of SOCS-3 mRNA in breast cancer with lymph node metastasis. Oncol Rep 2008; 19:33-9; PMID:18097573.

64. Waters MJ, Hoang HN, Fairlie DP, Pelekanos RA, Brown RJ. New insights into growth hormone action. J Mol Endocrinol 2006; 36:1-7; PMID:16461922; http://dx.doi.org/10.1677/jme.1.01933

65. Evans MK, Yu CR, Lohani A, Mahdi RM, Liu $\mathrm{X}$, Trzeciak AR, et al. Expression of SOCS1 and SOCS3 genes is differentially regulated in breast cancer cells in response to proinflammatory cytokine and growth factor signals. Oncogene 2007; 26:19418; PMID:17001312; http://dx.doi.org/10.1038/ sj.onc. 1209993

66. Guillem V, Amat P, Cervantes F, Alvarez-Larrán A, Cervera J, Maffioli M, et al. Functional polymorphisms in SOCS1 and PTPN22 genes correlate with the response to imatinib treatment in newly diagnosed chronic-phase chronic myeloid leukemia. Leuk Res 2012; 36:174-81; PMID:21724255; http://dx.doi. org/10.1016/j.leukres.2011.06.011

67. Butterbach K, Beckmann L, de Sanjosé S, Benavente Y, Becker N, Foretova L, et al. Association of JAKSTAT pathway related genes with lymphoma risk: results of a European case-control study (EpiLymph). Br J Haematol 2011; 153:318-33; PMID:21418178; http://dx.doi.org/10.1111/j.1365-2141.2011.08632.x

68. Slattery ML, Lundgreen A, Kadlubar SA, Bondurant KL, Wolff RK. JAK/STAT/SOCS-signaling pathway and colon and rectal cancer. Mol Carcinog 2013; 52:155-66; PMID:22121102; http://dx.doi. org/10.1002/mc.21841

69. Butterbach K, Beckmann L, de Sanjosé S, Benavente Y, Becker N, Foretova L, et al. Association of JAKSTAT pathway related genes with lymphoma risk: results of a European case-control study (EpiLymph). Br J Haematol 2011; 153:318-33; PMID:21418178; http://dx.doi.org/10.1111/j.1365-2141.2011.08632.x

70. Hirano T, Ishihara K, Hibi M. Roles of STAT3 in mediating the cell growth, differentiation and survival signals relayed through the IL- 6 family of cytokine receptors. Oncogene 2000; 19:2548-56; PMID:10851053; http://dx.doi.org/10.1038/sj.onc.1203551

71. Xu Q, Briggs J, Park S, Niu G, Kortylewski M, Zhang S, et al. Targeting Stat3 blocks both HIF-1 and VEGF expression induced by multiple oncogenic growth signaling pathways. Oncogene 2005; 24:555260; PMID:16007214; http://dx.doi.org/10.1038/ sj.onc. 1208719
72. Williams L, Bradley L, Smith A, Foxwell B. Signal transducer and activator of transcription 3 is the dominant mediator of the anti-inflammatory effects of IL-10 in human macrophages. J Immunol 2004; 172:567-76; PMID: 14688368

73. Niu G, Wright KL, Ma Y, Wright GM, Huang M, Irby $\mathrm{R}$, et al. Role of Stat3 in regulating p 53 expression and function. Mol Cell Biol 2005; 25:743240; PMID:16107692; http://dx.doi.org/10.1128/ MCB.25.17.7432-7440.2005

74. Sitko JC, Yeh B, Kim M, Zhou H, Takaesu G, Yoshimura A, et al. SOCS3 regulates p21 expression and cell cycle arrest in response to DNA damage. Cell Signal 2008; 20:2221-30; PMID:18793717; http:// dx.doi.org/10.1016/j.cellsig.2008.08.011

75. Tebbutt NC, Giraud AS, Inglese M, Jenkins B, Waring $\mathrm{P}$, Clay FJ, et al. Reciprocal regulation of gastrointestinal homeostasis by SHP2 and STAT-mediated trefoil gene activation in gp130 mutant mice. Nat Med 2002; 8:1089-97; PMID:12219085; http://dx.doi. org/10.1038/nm763

76. Feldman DE, Chen C, Punj V, Tsukamoto H, Machida K. Pluripotency factor-mediated expression of the leptin receptor (OB-R) links obesity to oncogenesis through tumor-initiating stem cells. Proc Natl Acad Sci U S A 2012; 109:829-34; PMID:22207628; http:// dx.doi.org/10.1073/pnas.1114438109

77. Endo H, Hosono K, Uchiyama T, Sakai E, Sugiyama $\mathrm{M}$, Takahashi $\mathrm{H}$, et al. Leptin acts as a growth factor for colorectal tumours at stages subsequent to tumour initiation in murine colon carcinogenesis. Gut 2011; 60:1363-71; PMID:21406387; http://dx.doi. org/10.1136/gut.2010.235754

78. Park J, Scherer PE. Leptin and cancer: from cancer stem cells to metastasis. Endocr Relat Cancer 2011; 18:C259; PMID:21680729; http://dx.doi.org/10.1530/ERC11-0163

79. Rigby RJ, Simmons JG, Greenhalgh CJ, Alexander WS Lund PK. Suppressor of cytokine signaling 3 (SOCS3) limits damage-induced crypt hyper-proliferation and inflammation-associated tumorigenesis in the colon. Oncogene 2007; 26:4833-41; PMID:17297444; http://dx.doi.org/10.1038/sj.onc.1210286

80. Grivennikov SI, Greten FR, Karin M. Immunity, inflammation, and cancer. Cell 2010; 140:883-99; PMID:20303878; http://dx.doi.org/10.1016/j. cell.2010.01.025

81. Roder DM. The epidemiology of gastric cancer. Gastric Cancer 2002; 5(Suppl 1):5-11; PMID:12772880; http://dx.doi.org/10.1007/s10120-002-0203-6

82. Koike K. Molecular basis of hepatitis C virus-associated hepatocarcinogenesis: lessons from anima model studies. Clin Gastroenterol Hepatol 2005; 3(Suppl 2):S132-5; PMID:16234061; http://dx.doi. org/10.1016/S1542-3565(05)00700-7

83. Haverkamp J, Charbonneau B, Ratliff TL. Prostate inflammation and its potential impact on prostate cancer: a current review. J Cell Biochem 2008; 103:134453; PMID:17955503; http://dx.doi.org/10.1002/ jcb. 21536

84. Bollrath J, Phesse TJ, von Burstin VA, Putoczki T, Bennecke M, Bateman T, et al. gp130-mediated Stat3 activation in enterocytes regulates cell survival and cellcycle progression during colitis-associated tumorigenesis. Cancer Cell 2009; 15:91-102; PMID:19185844; http://dx.doi.org/10.1016/j.ccr.2009.01.002

85. Grivennikov SI, Greten FR, Karin M. Immunity, inflammation, and cancer. Cell 2010; 140:883-99; PMID:20303878; http://dx.doi.org/10.1016/j. cell.2010.01.025

86. Giraud AS, Menheniott TR, Judd LM. Targeting STAT3 in gastric cancer. Expert Opin Ther Targets 2012; 16:889-901; PMID:22834702; http://dx.doi.org $/ 10.1517 / 14728222.2012 .709238$

87. Rebouissou S, Amessou M, Couchy G, Poussin K, Imbeaud S, Pilati $\mathrm{C}$, et al. Frequent in-frame somatic deletions activate gp130 in inflammatory hepatocellular tumours. Nature 2009; 457:200-4; PMID:19020503; http://dx.doi.org/10.1038/nature07475
88. Mantovani A, Allavena P, Sica A, Balkwill F. Cancerrelated inflammation. Nature 2008; 454:436-44; PMID:18650914; http://dx.doi.org/10.1038/ nature 07205

89. Mantovani A. Cancer: Inflaming metastasis. Nature 2009; 457:36-7; PMID:19122629; http://dx.doi. org/10.1038/457036b

90. Tye H, Kennedy CL, Najdovska M, McLeod L, McCormack W, Hughes N, et al. STAT3-driven upregulation of TLR2 promotes gastric tumorigenesis independent of tumor inflammation. Cancer Cell 2012; 22:466-78; PMID:23079657; http://dx.doi. org/10.1016/j.ccr.2012.08.010

91. Hold GL, Rabkin CS, Chow WH, Smith MG, Gammon MD, Risch HA, et al. A functional polymorphism of toll-like receptor 4 gene increases risk of gastric carcinoma and its precursors. Gastroenterology 2007; 132:905-12; PMID:17324405; http://dx.doi. org/10.1053/j.gastro.2006.12.026

92. Tahara T, Arisawa T, Wang F, Shibata T, Nakamura M, Sakata M, et al. Toll-like receptor $2-196$ to $174 \mathrm{del}$ polymorphism influences the susceptibility of Japanese people to gastric cancer. Cancer Sci 2007; 98:1790-4; PMID:17711514; http://dx.doi.org/10.1111/j.13497006.2007.00590.x

93. Huang Y, Feld JJ, Sapp RK, Nanda S, Lin JH, Blatt LM, et al. Defective hepatic response to interferon and activation of suppressor of cytokine signaling 3 in chronic hepatitis C. Gastroenterology 2007; 132:73344; PMID:17258724; http://dx.doi.org/10.1053/j.gastro.2006.11.045

94. Shen L, Evel-Kabler K, Strube R, Chen SY. Silencing of SOCS1 enhances antigen presentation by dendritic cells and antigen-specific anti-tumor immunity. Nat Biotechnol 2004; 22:1546-53; PMID:15558048; http://dx.doi.org/10.1038/nbt1035

95. Evel-Kabler K, Song XT, Aldrich M, Huang XF, Chen SY. SOCS1 restricts dendritic cells' ability to break self tolerance and induce antitumor immunity by regulating IL-12 production and signaling. J Clin Invest 2006; 116:90-100; PMID:16357940; http://dx.doi. org/10.1172/JCI26169

96. Hanada T, Tanaka K, Matsumura Y, Yamauchi M, Nishinakamura $\mathrm{H}$, Aburatani $\mathrm{H}$, et al. Induction of hyper Th1 cell-type immune responses by dendritic cells lacking the suppressor of cytokine signaling-1 gene. J Immunol 2005; 174:4325-32; PMID:15778397.

97. Du R, Lu KV, Petritsch C, Liu P, Ganss R, Passegué $\mathrm{E}$, et al. HIF1alpha induces the recruitment of bone marrow-derived vascular modulatory cells to regulate tumor angiogenesis and invasion. Cancer Cell 2008; 13:206-20; PMID:18328425; http://dx.doi. org/10.1016/j.ccr.2008.01.034

98. Wu L, Du H, Li Y, Qu P, Yan C. Signal transducer and activator of transcription 3 (Stat3C) promotes myeloid-derived suppressor cell expansion and immune suppression during lung tumorigenesis. Am J Pathol 2011; 179:2131-41; PMID:21864492; http://dx.doi. org/10.1016/j.ajpath.2011.06.028

99. Whyte CS, Bishop ET, Rückerl D, Gaspar-Pereira S, Barker RN, Allen JE, et al. Suppressor of cytokine signaling (SOCS) 1 is a key determinant of differential macrophage activation and function. J Leukoc Biol 2011; 90:845-54; PMID:21628332; http://dx.doi. org/10.1189/jlb.1110644

100. Wang YC, He F, Feng F, Liu XW, Dong GY, Qin HY, et al. Notch signaling determines the M1 versus M2 polarization of macrophages in antitumor immune responses. Cancer Res 2010; 70:4840-9; PMID:20501839; http://dx.doi.org/10.1158/00085472.CAN-10-0269

101. Hiwatashi K, Tamiya T, Hasegawa E, Fukaya T, Hashimoto M, Kakoi K, et al. Suppression of SOCS3 in macrophages prevents cancer metastasis by modifying macrophage phase and MCP2/CCL8 induction. Cancer Lett 2011; 308:172-80; PMID:21624767; http://dx.doi.org/10.1016/j.canlet.2011.04.024 
102. Spence S, Fitzsimons A, Boyd CR, Kessler J, Fitzgerald $\mathrm{D}$, Elliott J, et al. Suppressors of cytokine signaling 2 and 3 diametrically control macrophage polarization. Immunity 2013; 38:66-78; PMID:23177319; http:// dx.doi.org/10.1016/j.immuni.2012.09.013

103. Parrillas V, Martínez-Muñoz L, Holgado BL, Kumar A, Cascio G, Lucas P, et al. Suppressor of cytokine signaling 1 blocks mitosis in human melanoma cells. Cell Mol Life Sci 2013; 70:545-58; PMID:23001011; http://dx.doi.org/10.1007/s00018-012-1145-8

104. Cooper JC, Shi M, Chueh FY, Venkitachalam S, Yu CL. Enforced SOCS1 and SOCS3 expression attenuates Lck-mediated cellular transformation. Int J Oncol 2010; 36:1201-8; PMID:20372794.

105. Lin YC, Lin CK, Tsai YH, Weng HH, Li YC, You L, et al. Adenovirus-mediated SOCS3 gene transfer inhibits the growth and enhances the radiosensitivity of human non-small cell lung cancer cells. Oncol Rep 2010; 24:1605-12; PMID:21042758.
106. Cui Q, Jiang W, Wang Y, Lv C, Luo J, Zhang W, et al. Transfer of suppressor of cytokine signaling 3 by an oncolytic adenovirus induces potential antitumor activities in hepatocellular carcinoma. Hepatology 2008; 47:105-12; PMID:17935223; http://dx.doi. org/10.1002/hep.21951

107. Shouda T, Hiraoka K, Komiya S, Hamada T, Zenmyo M, Iwasaki H, et al. Suppression of IL-6 production and proliferation by blocking STAT3 activation in malignant soft tissue tumor cells. Cancer Lett 2006; 231:176-84; PMID:16399222; http://dx.doi. org/10.1016/j.canlet.2005.01.042

108. Flowers LO, Subramaniam PS, Johnson HMA. A SOCS-1 peptide mimetic inhibits both constitutive and IL-6 induced activation of STAT3 in prostate cance cells. Oncogene 2005; 24:2114-20; PMID:15688010; http://dx.doi.org/10.1038/sj.onc. 1208437
109. Liang P, Cheng SH, Cheng CK, Lau KM, Lin SY, Chow EY, et al. Platelet factor 4 induces cell apoptosis by inhibition of STAT3 via up-regulation of SOCS3 expression in multiple myeloma. Haematologica 2013; 98:288-95; PMID:22929979; http://dx.doi org/10.3324/haematol.2012.065607

110. Hu Q, Qin X, Qian G, Jiang S, Li H, Jiang M, et al. SOCS1 silencing can break high-dose dendritic cell immunotherapy-induced immune tolerance. Mol Med Rep 2008; 1:61-70; PMID:21479379.

111. Song S, Wang Y, Wang J, Lian W, Liu S, Zhang Z, et al. Tumour-derived IL-10 within tumour microenvironment represses the antitumour immunity of Socs 1 silenced and sustained antigen expressing DCs. Eur J Cancer 2012; 48:2252-9; PMID:22230748; http:// dx.doi.org/10.1016/j.ejca.2011.12.009 